\title{
O "super-homem" e o "pai da horda": considerações éticas ${ }^{1}$
}

\author{
Simone Perelson ${ }^{2}$ \\ Universidade Federal do Rio de Janeiro, Rio de Janeiro-RJ, Brasil
}

\begin{abstract}
Resumo: O artigo analisa a aproximação proposta por Freud entre o "pai da horda primitiva," por ele referido em Totem e $T a b u$, e a noção de "super-homem" referida por Nietzsche em Assim falou Zaratustra. Por meio desta análise, serão abordados: (1) problemas presentes na interpretação freudiana da noção de "super-homem", (2) diferenças entre Freud e Nietzsche no que concerne à compreensão da "autarquia" e da "desconsideração pela lei", aspectos próprios, segundo Freud, tanto do "super-homem" quanto do "pai da horda" e (3) diferença entre o "desprezo pela moral" reivindicado por Freud e a defesa nietzschiana de uma "moral baseada na transmutação de todos os valores".
\end{abstract}

Palavras-chave: pai, Freud, moral.

\section{The "superman" and the "horde father": ethical considerations}

\begin{abstract}
The paper examines the approach proposed by Freud between the 'father of the primal horde' referred to in Totem and Taboo and the concept of 'superman' described by Nietzsche in Thus Spoke Zarathustra. Based on this analysis, the following points are discussed: (1) problems addressed in the Freudian interpretation of the concept of 'Superman'; (2) differences between Freud and Nietzsche regarding the understanding of 'authority' and 'disregard for the Law', singular aspects, according to Freud, both of the 'superman' as well as the 'father of the horde' and (3) difference between 'contempt for moral' claimed by Freud and Nietzsche's advocacy of a 'morality based on the transmutation of all values'.
\end{abstract}

Keywords: father, Freud, moral.

\section{"El superhombre" y "el padre de la horda": consideraciones éticas}

Resumen: El artículo analiza el acercamiento propuesto por Freud entre el "padre de la horda primitiva" al que se refiere en Totem y Tabu y el concepto de "superhombre" descripto por Nietzsche en Asi habló Zaratustra. Serán tratados, a través de este análisis: (1) problemas presentes en la interpretación freudiana del concepto de "superhombre"; (2) diferencias entre Freud y Nietzsche en lo concerniente a la comprensión de la "autarquia" y de la "desconsideración de la ley", aspectos propios, según Freud, tanto del "superhombre" como del "padre de la horda", y (3) diferencia entre el "desprecio de la moral" reivindicado por Freud y la defensa nietzscheana de una "moral basada en la transmutación de todos los valores".

Palabras clave: padre, Freud, moral.

Em Psicologia das massas e análise do eu, encontramos a seguinte afirmação de Freud: "No início da história da humanidade, se encontrava o super-homem que Nietzsche somente esperava do futuro" (Freud, 1921/1981, p. 191). Nesta afirmação, nos são simultaneamente sugeridas, por um lado, a identificação empreendida por Freud entre o superhomem descrito por Nietzsche no livro Assim falou Zaratustra (Nietzsche, 1884/1971) e o pai da horda primitiva descrito por ele mesmo em Totem e Tabu (Freud, 1913/1993) e, por outro lado, a distância que separa os dois autores, a respeito deste ponto comum: enquanto o filósofo o espera em um futuro pós-histórico, o psicanalista o situa no passado pré-histórico.

Como sabemos, segundo Freud, o assassinato do pai da horda, isto é, do pai violento e ciumento que conservava para si todas as fêmeas e expulsava pela força os filhos à medida que cresciam, assassinato cometido por seus próprios

\footnotetext{
${ }^{1}$ Este texto foi revisado segundo Acordo Ortográfico da Língua Portuguesa (1990), em vigor a partir de $1^{\circ}$ de janeiro de 2009.

${ }^{2}$ Endereço para correspondência:

Simone Perelson. Rua Humberto de Campos, 974/1602. CEP: 22.430190, Rio de Janeiro - RJ, Brasil. E-mail: simoneperelson@oi.com.br
}

filhos, é a condição de possibilidade para o surgimento da moralidade. Em primeiro lugar, a ambivalência dos sentimentos filiais, que vêm à tona com a morte do pai, funda a culpabilidade. Em segundo lugar, impulsionados pelos sentimentos afetivos que nutriam pelo pai, os filhos o dotam de um poder ainda maior do que este dispunha em vida, transformando-o, primeiramente em totem, e posteriormente em Deus, e proibindo eles próprios o que até então fora proibido pelo pai: o acesso às mulheres do clã. Como observa Freud (1923/1993):

A sociedade estava agora baseada na cumplicidade do crime comum; a religião baseava-se no sentimento de culpa e no remorso a ele ligado; enquanto que a moralidade fundamentava-se parte nas exigências dessa sociedade e parte na penitência exigida pelo sentimento de culpa (Freud, 1913/1993, p. 174).

Está claro, então, em que medida, segundo Freud, a morte do pai da horda se encontra no início da história da moralidade humana. Nietzsche, por sua vez, espera encontrar, não no início, mas no futuro dessa mesma história, o super-homem. E, mais ainda, enquanto Freud afirma encontrar na origem da história da moralidade a morte do pai da 
horda, Nietzsche espera encontrar, ao termo feliz dessa história, o nascimento do super-homem, nascimento este que só pode resultar da morte do homem e da transmutação da moral. Portanto, se, para Freud, é a morte do pai da horda que permite o nascimento do homem moral, para Nietzsche, ao contrário, é a morte do homem moral que permite o nascimento do "super-homem".

Cabe agora buscarmos analisar o sentido da aproximação empreendida por Freud entre o pai da horda e o superhomem, assim como o da diferença por ele apontada entre os lugares que ele mesmo, por um lado, e Nietzsche, por outro, reservam para a figura do pai da horda/super-homem. Com esta análise, objetivamos extrair o máximo de sentido da frase freudiana presente no texto sobre a Psicologia das massas, de modo a podermos indicar de modo mais claro em que medida a ética freudiana aproxima-se e/ou distancia-se da moral nietzschiana.

Antes, entretanto, de abordarmos o sentido das aproximações e distanciamentos conceituais que Freud aponta entre suas formulações sobre o pai da horda e as formulações nietzschianas sobre o super-homem, cabe indicarmos o modo segundo o qual se dá a aproximação de Freud com o pensamento nietzschiano. Como observa Paul-Laurent Assoun, essa aproximação é marcada ao mesmo tempo pela insistência e pela negação, ou ainda por um "misto de admiração, atração e inquietude" (Assoun, 1980/1989, p. 40). Com efeito, se as referências freudianas a Nietzsche são bastante recorrentes, Freud não deixa de indicar explicitamente que nunca leu o filósofo, e isso não por falta de interesse, mas, pelo contrário, por temor de que o excesso de interesse que suas ideias the despertavam pudesse exercer sobre ele uma influência maior do que desejava receber da filosofia e, mais particularmente, do filósofo. Portanto, é necessário guardarmos uma certa cautela ao abordarmos a leitura empreendida por Freud dos conceitos nietzschianos. Não podemos perder de vista que a leitura que Freud fez do filósofo é bastante limitada e sujeita a inúmeras deturpações. Entretanto, mesmo levando em consideração as limitações dessa leitura, julgamos que a análise das aproximações e diferenças que Freud sugere entre a sua forma de conceber a moral e o que ele concebe como sendo a moral nietzschiana podem em muito contribuir para a abordagem de alguns importantes aspectos da moral freudiana.

\section{A interpretação freudiana do super-homem nietzschiano}

Como mostra Paul-Laurent Assoun (1980/1989), a descrição dada por Freud do pai da horda nos permite evidenciar o primeiro ponto comum que ele encontra entre este e o super-homem: "a autarquia". Tais são os termos de Freud para descrever a autarquia do pai da horda:

Os indivíduos da massa achavam-se sujeitos a vínculos tais como os que percebemos hoje, mas o pai da horda originária era livre. Seus atos intelectuais eram, mesmo em seu isolamento, fortes e independentes, sua vontade não precisava ser reforçada pela dos outros. (Freud, 1921/1981, p. 191. O grifo é nosso)

De fato, se consideramos os elementos sublinhados nessa passagem - a força e a independência da vontade -, podemos acreditar numa efetiva relação entre o "super-homem" e o "pai da horda". No entanto, como mostra ainda Assoun (1980/1989), Freud concebe esta autarquia como uma forma de narcisismo hipertrofiado ou, em outros termos, como o superdesenvolvimento do ego. Efetivamente, o que explica, segundo Freud, a força e a independência da vontade do pai da horda é o fato de que "seu ego possuía poucos vínculos libidinais: ele não amava a ninguém, a não ser a si próprio e não amava outras pessoas senão na medida em que serviam às sua necessidades" (Freud, 1921/1981, p. 191). Ora, se nos lembrarmos da lógica freudiana que estabelece uma relação inversa entre a libido do objeto e a libido do eu, logo entenderemos que a ausência de investimento objetal se transforma nesse narcisismo hipertrofiado ou nesse "hiperdesenvolvimento" do eu.

Portanto, ao associar o "super-homem" ao "pai da horda", a partir do elemento comum da autarquia, e ao ligar esta à ausência de laços libidinais ou à hipertrofia do narcisismo, Freud nos esclarece não apenas a sua interpretação do super-homem, mas também a articulação que ele estabelece entre este último e o pai da horda. Tanto um quanto o outro manifestam, para Freud, o "privilégio soberano do narcisismo primário" que se exprime por uma "suprema indiferença pelo outro" (Assoun, 1980/1989, p. 78).

Se compreendermos que é nesses termos que Freud funda a sua articulação, não iremos nos surpreender com aquilo que, ao ver de Assoun, deve ser destacado da abordagem freudiana do super-homem, a saber, o fato de que "Freud não espera nem deseja a vinda de um Super-homem" (Assoun, 1980/1989, p. 79) e que, diferentemente de Nietzsche, ele situa, não no futuro, mas num antes interrompido e caduco aquele que ele define como o tipo acabado do mais integral narcisismo concebível para o homem. Da mesma maneira, não devemos ficar surpresos se, enquanto Nietzsche articula a moralidade superior à vinda do super-homem, Freud funda o nascimento da moral na sua morte. Finalmente, se aceitarmos essa interpretação freudiana do super-homem, chegaremos, junto com Assoun, à seguinte conclusão: "assim como a moralidade no sentido freudiano deve ser procurada do lado do Superego, a 'moralidade' superior em Nietzsche deve ser procurada do lado do Ideal do Ego ou do Ego ideal" (Assoun, 1980/1989, p. 291).

Tendo definido o primeiro ponto comum que Freud estabelece entre o super-homem e o pai da horda primitiva como "a suprema indiferença em relação ao outro", abordemos agora o segundo ponto de articulação, que demonstra uma ligação com o primeiro: trata-se dessa mesma suprema indiferença, mas em relação à lei. 
É ainda Assoun quem nos indica não apenas esse elemento de articulação, mas também a passagem em que Freud o enuncia. No manuscrito datado de 31 de maio de 1887 e endereçado a Fliess, Freud se refere ao super-homem como a única exceção à submissão à interdição do incesto; interdição que, como se sabe, está na origem de todas as outras, e da qual só está liberto o pai da horda original. Cabe a Assoun citar a passagem em que esta ideia é apresentada: "Freud afirma aí que 'incesto é um fato anti-social ao qual para existir, a civilização teve que renunciar pouco a pouco'. Neste ponto preciso, ele acrescenta: 'O oposto é o super-homem'” (Assoun, 1980/1989, p. 79).

Como observa o autor, a imagem do "super-homem/ pai primitivo" sugerida nessa passagem é a de alguém que goza de uma satisfação imediata e ilimitada, na qual o princípio do prazer se exerce sem nenhum constrangimento. O super-homem é indiferente à mediação da lei, de modo que ele "designa o infinito de satisfação cuja única racionalidade e moralidade reduz-se ao noch einmal, mais ainda!" (Assoun, 1980/1989, p. 306). Da mesma forma, sustenta Assoun, ele é indiferente às figuras da mediação ou às significações da lei, a saber, o remorso, o arrependimento, o ressentimento e seus derivados: a culpa, a má consciência, a piedade; enfim, todas as espécies da psicopatologia ético-religiosa. Assim, se aceitarmos como legítima essa interpretação freudiana do super-homem - e se lembrarmos que, enquanto para Nietzsche, ele é a expressão de uma moralidade superior, de uma "moralidade sã", para Freud, ao contrário, o nascimento da moral implica a sua morte -, seremos levados a aceitar a diferença estabelecida por Assoun entre as concepções da doença em Freud e em Nietzsche. Ao ver do comentador, enquanto a doença (a neurose) decorre, para Freud, de uma falha na relação com a lei - falha que o tratamento tem por função sanar -, para Nietzsche, ao contrário, a doença (moral) decorre da própria submissão à lei, submissão essa que deve ser superada por uma transvaloração radical.

A essa diferença de concepção da doença se associa evidentemente, ainda ao ver de Assoun, uma diferença a respeito da concepção da cura. Como observa ele, enquanto, para Nietzsche, curar o homem é fazê-lo superar o homem e a lei, para Freud, curar o homem é fazê-lo superar a distância entre seu desejo e a lei.

\section{O questionamento da interpretação freudiana do super-homem nietzschiano}

Tendo explicitado os pontos comuns estabelecidos por Freud entre o super-homem e o pai primitivo, assim como as diferenças éticas e clínicas entre Freud e Nietzsche levantadas por Assoun, a partir da análise das passagens em que Freud explicita esses pontos comuns, é preciso agora indicar em que sentido podem ser questionadas tanto a interpretação freudiana do super-homem quanto as derivações éticas dessa interpretação indicadas por Assoun.
Comecemos analisando o primeiro ponto de comparação notado por Freud entre o super-homem e o pai da horda, a saber, a força e a independência da vontade. Para indicar a diferença entre as concepções de independência de Nietzsche e de Freud, vamos nos referir a uma passagem de Além do bem e do mal, na qual Nietzsche descreve justamente "a mais forte prova de independência" (Nietzsche, 1886/1971, p. 59). Uma primeira leitura dessa passagem pode nos levar a acreditar que o desprendimento do investimento objetal também é para ele a condição necessária da independência, e isso porque ele afirma que a prova da independência se encontra no fato de não se prender a nenhuma pessoa, a nenhuma pátria, a nenhuma compaixão, a nenhuma ciência (Nietzsche, 1886/1971, p. 58).

No entanto, uma pequena sutileza no seu texto nos esclarece a respeito da sua diferença em relação a Freud: depois de ter afirmado que não devemos nos prender a ninguém, ele continua: "por mais amada que seja, qualquer pessoa é uma prisão, e também um refúgio" (Nietzsche, 1886/1971, p. 58). Assim, não se trata de não amar ninguém, mas de não fazer dessa pessoa um refúgio ou uma prisão; de "saber se preservar" (Nietzsche, 1886/1971, p. 59). Eis a diferença entre a independência do super-homem e a do pai da horda: enquanto este último não ama ninguém, a não ser aquele que lhe serve, o primeiro não transforma seu amor em dependência. A sobre-humanidade implica uma mudança de relação com o outro, e não uma perda de investimento do objeto.

Se tentarmos entender essa independência da qual nos fala Nietzsche, a partir do que nos ensina a psicanálise, podemos afirmar que ela supõe uma relação com o outro na qual não se espera deste que responda às perguntas do sujeito, nem que preencha suas necessidades, nem tampouco que autorize seu desejo. Compreendida assim, a independência, mais do que exprimir uma indiferença narcísica ao olhar do outro, supõe a experiência do investimento em um outro que se sabe precário, frágil e inconsistente.

Da mesma forma que não compreendemos que a noção de independência nietzschiana implique a falta de investimentos libidinais, tampouco pensamos que ela remeta a um hiperdesenvolvimento do eu. Com efeito, o advento do super-homem, mais do que implicar um progresso ou uma fortificação do eu, implica a sua perda, seu apagamento; ou seja, o caminho rumo à sobre-humanidade é um caminho de desprendimento de si enquanto identificação estável, enquanto eu forte, enquanto imagem narcísica. Como afirma Nietzsche, "quando conseguimos encontrar nós mesmos, é preciso consentir em se perder de tempos em tempos" (Nietzsche, 1880/1995, p. 672). O super-homem se encontra, então, nessa perda, ou, como afirma Heidegger, nos indicando a que ponto ele se opõe à rigidez do eu, "o Super-homem passa além do modo de ser do homem até aqui conhecido: assim, ele é uma passagem, um ponto" (Heidegger, 1958/2008, p. 124. O grifo é nosso).

Abordemos agora o segundo ponto: a questão da indiferença à lei. Como observamos, o super-homem se encontra, 
segundo Freud, no mesmo local lógico que o pai da horda, aquele da exceção em relação à submissão à lei. E, como observou Assoun, o super-homem é indiferente não apenas à lei, mas também às suas significações, ou seja, a todas as espécies da psicopatologia ético-religiosa.

Se questionamos aqui as interpretações de Freud e de Assoun, é porque acreditamos que o super-homem, apesar de estar além da "psicopatologia ético-religiosa", não está além da lei: o super-homem está liberto da culpabilidade, e não da lei. Dito de outra maneira, ele está além de uma certa significação da lei, e não da lei tout court. Nada mais distante da vontade autônoma, insiste Nietzsche, do que o simples "laisser-aller"; nada mais próximo da liberdade do que a rigorosa obediência à lei. Como observa o filósofo, neste belo trecho de Além do bem e do mal,

Tudo o que existe ou existiu na terra em termos de liberdade (...) jamais se desenvolveu, tanto na ordem artística quanto na ordem moral, senão graças à tirania dessas 'leis arbitrárias': é nisso, segundo todas as aparências, que se encontra a 'natureza' e o 'natural', e não no laisser-aller (Nietzsche, 1886/1971, p. 101).

Até mesmo na criação artística, lócus privilegiado da experiência da liberdade, a lei, sustenta o filósofo, impera. Segundo seus termos:

Todo artista sabe o quanto o seu estado mais natural está longe do laisser-aller, quando, em plena liberdade, nos momentos de 'inspiração', ele ordena, agencia, dispõe, informa a sua matéria, e com que exatidão, de que maneira sutil, ele obedece a múltiplas leis, cujo rigor e precisão, desafiam qualquer formulação conceitual (Nietzsche, 1886/1971, p. 101).

Enfim, conclui Nietzsche (1886/1971):

O que importa antes de tudo, 'tanto na terra quanto no céu', ao que parece, é obedecer por um longo período, e num único sentido: com o tempo, surge e sempre surgiu algo pelo que vale a pena viver, virtude, arte, música, dança, razão, espiritualidade, qualquer coisa de transfigurante, refinado, louco, divino (Nietzsche, 1886/1971, p. 101).

A articulação entre liberdade e obediência durável à lei a qual se refere Nietzsche nesses trechos citados não deixa de estar presente no super-homem. E é por isso que, como observa Heidegger, enganamo-nos - e engana-se Freud, podemos observar - ao compreender que com o termo super-homem, Nietzsche pense "uma espécie de homem que descarta o humano e que faz da arbitrariedade nua e crua da lei e da fúria titânica, a regra" (Heidegger, 1958/2008, p. 91).
Concluímos, portanto, junto com o filósofo, e contra Freud, que "a essência do super-homem não é licença a um arbitrário desmesurado" (Heidegger, 1949/1962, p. 306). Assim, da mesma maneira que, contra toda idealização, o super-homem não deve ser pensado como o acabamento da perfeição humana, ou ainda, como afirma Heidegger (1949/1962), não deve ser confundido com algum espécime isolado do gênero humano, no qual as capacidades e objetivos habitualmente conhecidos teriam se desenvolvido de forma extraordinariamente superior a dos outros homens; tampouco ele deve ser compreendido como um tirano, como um animal selvagem desconhecedor de todo respeito, amor ou lei.

Se nos parece que já indicamos suficientemente em que sentido recusamos o paralelo proposto por Freud entre o super-homem e o "pai da horda", ao enfatizar que o superhomem não está absolutamente liberto de toda lei, é preciso agora voltar ao sentido de sua moralidade. De fato, a "moral sobre-humana" é concebida por Nietzsche como uma moralidade na qual a lei não se traduz nessa "psicopatologia ético-religiosa". Assim, o livre exercício da vontade de potência está curado, como mostra Assoun, de toda forma de culpabilidade, piedade ou remorso. E neste ponto concordamos em absoluto com esse autor, quando ele opõe Freud a Nietzsche: tal como a psicanálise o descobre, o desejo não se separa nunca dessas "figuras psicopatológicas" que simultaneamente a ele reagem e provocam-no. De fato, como observa Assoun, "é ali onde se sente culpado que o sujeito deseja" (Assoun, 1980/1998, p. 35). Não há lugar, na psicanálise, para se pensar uma lei pura, depurada de toda reatividade, nem um sujeito puro, depurado de toda culpabilidade.

\section{A altura nietzschiana e o subsolo freudiano}

Ao ver de Assoun (1980/1988), é a recusa freudiana em pensar uma lei, um sujeito ou um desejo puro que explica o fato de que ali onde o pensamento nietzschiano parece a Freud excessivamente idealista, abstrato ou moralizante, o psicanalista tome um rumo oposto ao do filósofo. Freud, então, se distanciaria de Nietzsche quando este lhe parece tomar um caminho de elevação, se dirigir às "alturas", aos cumes. Afasta-se dele também quando o filósofo lhe parece elevar a "nobreza" e o "super-homem" a categorias éticofilosóficas. Como ressalta Assoun, contra essa elevação ou esse caminho rumo aos cumes, contra a exaltação da nobreza e da sobre-humanidade, Freud insiste na sua profissão de fé: trabalhar no subsolo. Desta forma, sustenta o comentador, enquanto "a noção de Vornemheit [nobreza] ganhará cada vez mais impulso em Nietzsche até ser de algum modo 'instituída' pela noção de 'super-homem' (Ubermenschliches)" (Assoun, 1980/1998, p. 17), Freud "entendeu bem o que [essa] idéia implicava e se recusa, por sua vez, a candidatar-se à escalada de tais alturas" (idem). Um trecho de Ecce homo serve a Assoun para indicar essa diferença. Se nesse livro o filósofo afirma que aquele que sabe respirar a atmosfera que preenche sua obra sabe que é uma atmosfera das alturas, que 
o ar nela é vivo e que é preciso ser criado para essa atmosfera, Freud, por sua vez, sustenta Assoun, parece responder: "bem, eu não sou".

Da mesma forma, Freud se distancia de Nietzsche, observa ainda Assoun, quando o filósofo the parece glorificar as virtudes nobres ou exaltar a "tragicidade" da vontade de potência. Freud, ressalta o autor, utiliza mais a ironia do que a exaltação, e mais do que da tragédia, ele gosta do humor. Assoun cita aqui as palavras de Andler, as quais, afirma ele, se aplicam maravilhosamente a Freud: "O humor anima o pensamento que sabe que toda idealidade nobre é condicionada por uma realidade material grosseira, e o próprio pensamento por imagens grosseiras... E ele contempla esta fragilidade (do mundo) com um sorriso onde passa um enternecimento" (Andler, conforme citado por Assoun, 1980/1989, p. 50).

Por fim, conclui Assoun (1980/1988), Freud se distancia de Nietzsche quando o filósofo se faz moralista, transformando o ser em dever. Como ele mesmo afirma, "o que nos perturba é que Nietzsche transformou ser (ist) em dever (soll)" (Assoun, 1980/1989, p. 299). Por outro lado, observa ainda o autor, Freud também se distancia do filósofo quando ele enaltece um imoralismo radical, e isso porque "o que se demonstra no inconsciente não é alguma 'imoralidade' radical, de modo que, da mesma forma que qualquer $\mathrm{Wel}$ tanschauung moral, o ‘imoralismo’ tampouco convém à psicanálise" (Assoun, 1980/1998, p. 36).

A partir, sobretudo, da notação desses três pontos de divergência, Assoun consegue mostrar que, se Nietzsche fascinava enormemente Freud, pois tinha com ele numerosos pontos de encontro, este último recusava toda prova de idealismo, de abstração ou de moral que acreditava encontrar no filósofo. Entretanto, se estamos absolutamente de acordo com Assoun naquilo que concerne à demarcação da posição freudiana por oposição a toda idealização, abstração e moralização, questionamos a interpretação do pensamento nietzschiano que ele propõe ao confrontar Freud e o filósofo. De fato, se acreditamos ser possível interpretar Nietzsche, como faz Freud e com ele Assoun, como um glorificador dos cumes e de uma nobreza que não parecem interessar a Freud; se também é possível opor, como faz Assoun, a exaltação trágica de Nietzsche ao gosto pela zombaria em Freud; por fim, se não há dúvida de que Freud recusa todo julgamento moral enquanto Nietzsche é um moralista por excelência; resumindo, se tudo isso é verdade, não é menos verdade que a "transmutação" de todos os valores operada por Nietzsche também inverte em grande parte o sentido do que acabamos de afirmar.

Abordemos, portanto, os três pontos de divergência entre Freud e Nietzsche indicados acima por Assoun. Em primeiro lugar, no que concerne à glorificação nietzschiana dos cumes, acreditamos que não se deve considerá-la sem articulá-la a toda a importância que Nietzsche confere à decadência. Com efeito, Nietzsche é refratário a toda e qualquer ideia de aperfeiçoamento do homem e considera que a vinda do super-homem implica, mais do que um processo de elevação, aquele de uma queda. É por esta razão que ele faz Zaratustra afirmar: "amo aqueles que não sabem viver senão declinando" (Nietzsche, 1884/1971, p. 24) pois "a virtude é vontade de declínio" (Nietzsche, 1884/1971, p. 24). Lembremos também que o "alegre saber" é, para ele, mais do que ascendente, um saber declinante. Lembremos, por fim, que o próprio Nietzsche afirma desconfiar plenamente de todos os ideais e de todos os sentimentos sublimes.

No entanto, sendo, como todos nós, um filho de Platão, Freud, ao ouvir Nietzsche afirmar que sua atmosfera é a das alturas, acredita encontrar aqui um elogio da perfeição, dos sentimentos sublimes e dos ideais. Mas a altura nietzschiana é justamente o oposto da elevação platônica; e Freud, ao afirmar, de diversas maneiras, que seu lugar é no subsolo, longe de se distanciar de Nietzsche, encontra, uma vez mais, o filósofo.

Da mesma maneira, quando Nietzsche exalta a nobreza, não é em absoluto a uma ideia de perfeição, sublimidade ou idealidade que ele faz referência. Lembremos a esse propósito a analogia que ele estabelece entre si mesmo e o alquimista, indicando que transformou aquilo que é mais odiado, temido e desprezado pela humanidade em coisa preciosa, em ouro.

Naquilo que concerne ao segundo ponto de divergência que indica Assoun - a saber, a oposição entre a glorificação nietzschiana das virtudes nobres e o humor de Freud, o qual era marcado pela consciência de que toda idealidade esconde uma realidade material grosseira -, é possível reconsiderá-lo à luz de uma passagem de Nietzsche citada e comentada por Foucault. Citemos, em primeiro lugar, as palavras de Nietzsche: "Exaltar as origens - eis o exagero metafísico que reaparece na concepção de que no começo de todas as coisas se encontra o que há de mais precioso e de mais essencial" (Nietzsche, 1880/1995, p. 527). Ao comentar essa passagem, Foucault observa que a genealogia de Nietzsche é a busca, menos da origem metafísica das coisas, do que seu começo histórico. E isso porque, enquanto o pesquisador metafísico gosta de "acreditar que as coisas em seu início se encontravam em estado de perfeição; que elas saíram brilhantes das mãos do criador, ou na luz sem sombra da primeira manhã" (Foucault, 1982, p. 18), a história ensina, ao contrário, “a rir das solenidades da origem" (Foucault, 1982, p. 18). Se Foucault insiste no fato de que Nietzsche busca um começo histórico é porque "o começo histórico é baixo. Não no sentido de modesto ou de discreto como o passo da pomba, mas de derrisório, de irônico, próprio a desfazer todas as enfatuações" (Foucault, 1982, p. 18). Se levarmos, portanto, em conta as palavras de Nietzsche, assim como o comentário de Foucault a esse respeito, não vemos como negar que a observação de Assoun sobre o humor citada acima, mais do que opor Freud a Nietzsche, ressalta novamente a sua proximidade.

Venhamos ao último dos pontos de divergência indicados por Assoun, ou seja, a questão da moralidade. Aqui, concordamos, por um lado, e discordamos, por outro, com o 
autor. É verdade que se Nietzsche faz de toda a sua filosofia uma moral, a própria moral da "transmutação" de todos os valores, "moral dos fortes", da ação e da afirmação, Freud, por sua vez, rejeita, desconfia, e até despreza toda doutrina moral. "A ética me é estranha", afirma Freud, numa carta a Pfister (Freud, 1963/1966, p. 103). Mas é explicando as razões de seu desprezo pela ética que Freud se aproxima surpreendentemente de Nietzsche. Eis os termos nos quais ele se exprime:

Eu não quebro muito a minha cabeça a respeito do bem e do mal, mas na média, descobri muito pouco 'bem' nos homens. Pelo que sei, quer invoquem tal ou tal outra doutrina - ou nenhuma - não são em sua maioria senão canalhas (Freud, 1963/1966, p. 103).

Assim, mesmo se Freud não se propõe a formular uma moral, ele tem um julgamento moral bastante claro do homem, e é primeiramente nesse julgamento que Freud encontra Nietzsche. Mas, além desse encontro, é explicitando sua conviç̧ão moral pessoal que Freud aproxima-se espantosamente de Nietzsche. Segundo suas palavras: "Se é preciso falar de uma ética, professo, em meu nome, um ideal elevado, dos quais os ideais que conheço se distanciam em geral de uma maneira das mais lamentáveis" (Freud, 1963/1966, p. 103). De fato, ao ler essa passagem, poderíamos pensar que, mais do que de Freud, encontrar-se-iam aqui as palavras de Nietzsche.

No entanto, apesar do encontro entre Freud e Nietzsche no que concerne a seus julgamentos morais do homem e da sua ética, não se pode negar que, se Nietzsche transforma seu julgamento pessoal numa doutrina moral, Freud faz de seu julgamento a razão de seu desprezo por toda e qualquer doutrina moral. Cabe observar, portanto, que se Nietzsche faz de seu julgamento uma ação, para Freud, ele se transforma numa reação.

Assim, concluímos, e a esse respeito estamos de acordo com Assoun, que Freud, diferentemente de Nietzsche, se recusa a fazer de seu pensamento uma ética. Contudo, é em relação à segunda afirmação do autor a respeito da moralidade que questionamos a sua análise. Ora, como afirmara Assoun (1980/1988), Freud se distancia de Nietzsche não apenas porque esse último enaltece um moralismo, mas também porque seu moralismo se traduz em um imoralismo radical, ou seja, no exercício de uma vontade de potência liberto de toda lei. Como observou o autor, esse imoralismo não convém mais à psicanálise do que um moralismo qualquer, e isso por causa da estreita relação que esta estabelece entre o inconsciente e a lei.

Ora, como indicamos anteriormente, a moralidade superior enaltecida por Nietzsche não se confunde nem com um imoralismo - porque o super-homem está tão liberto da culpabilidade quanto não o está da lei -, nem com um amoralismo, e isso porque Nietzsche não rejeita a moral stricto sensu, mas uma certa moral, justamente a da culpabilidade, para substituí-la por outra, a da "transmutação" de todos os valores. Assim entendida, a moral nietzschiana convém perfeitamente ao inconsciente, do qual sabemos muito bem que está estritamente ligado à lei e absolutamente liberto de toda culpabilidade.

No entanto, é preciso ressaltar novamente um distanciamento entre Freud e Nietzsche: enquanto este concebe um mundo onde a lei se impõe sem se misturar à culpabilidade, aquele descobre um laço impossível de se desfazer entre esses dois termos. Mas não é menos verdadeiro que cada um desses termos tem um sentido próprio e uma relação diferente com o desejo, e, se concordamos totalmente com Assoun quando ele afirma que a lei protege o sujeito do desejo, não poderíamos afirmar a mesma coisa naquilo que diz respeito à culpabilidade. Sabe-se a que ponto sua experiência pode opor-se ao desejo, mesmo se o sujeito só deseja quando se sente culpado.

Sem nenhum interesse em formular uma moral, Freud não buscará separar os campos da culpabilidade e da lei, nem os da culpabilidade e do desejo. Separar esses termos seria entrar no universo do "dever", porque no universo do "ser" esses termos nunca se separam. Todavia, ao contrário de Freud, Lacan se aventurará por onde seu mestre não quis ir: ele proporá uma ética da psicanálise, e nessa ética ele separa, e até mesmo opõe, num enunciado bem claro, os termos até aqui misturados. Na última aula de seu seminário sobre a ética, Lacan propõe que "a única coisa da qual se possa ser culpado, pelo menos na perspectiva analítica, é de ter cedido de seu desejo" (Lacan, 1959/1988, p. 382). Em seguida, esclarece o sentido da sua proposição: não se trata de formular uma moral que culpabilize o sujeito quando este cede ao seu desejo, mas de formular uma moral a partir da constatação, na experiência, do fato de que ali onde o sujeito se sente culpado, pode-se sempre estar certo de que ele cedeu ao seu desejo.

Eis, de certa forma, uma moral da "transmutação" dos valores: enquanto a moral tradicional associa a culpabilidade à realização do desejo - o sujeito sempre se sente culpado quando, a despeito do mal que pode causar ao outro (ou mesmo a si próprio), não cede de seu desejo -, a moral psicanalítica associa a culpabilidade ao fato contrário de ter, em nome do bem do outro ou de si mesmo, cedido do desejo. Como observa Lacan, é o próprio Freud que nos lembra que "não é o mal, mas o bem que engendra a culpabilidade" (Lacan, 1974, p. 71). E, conclui ele, aproximando-se surpreendentemente de Nietzsche,

fazer as coisas em nome do bem, e mais ainda, em nome do bem do outro, eis o que está longe de nos colocar ao abrigo não apenas da culpabilidade, mas de todas as espécies de catástrofes interiores" (Lacan, 1974, p. 68).

Sabemos quantos mal-entendidos provocou a ética do desejo, entendida diversas vezes como afirmação da 
onipotência, como exigência inumana feita ao sujeito para realizar o impossível, como imposição de um caminho que só pode conduzi-lo à morte. Para nos opormos a essa interpretação da ética do desejo, cabe lembrar o laço entre o desejo e a culpabilidade que, como indicou Assoun (1980/1988), é observado por Freud. Sustentando a ideia de que, apesar de uma primeira impressão, Lacan e Freud não se opõem a respeito desse laço, acreditamos poder indicar em que sentido a ética do desejo em nada tem nada a ver com uma ética da onipotência.

Se é possível mostrar que Lacan (1974) não se opõe, aqui, a Freud, é porque, ao formular sua ética, ele nunca enaltece um universo sem culpabilidade onde o desejo se realiza sempre e em todos os lugares, e nesse sentido ele se afasta de Nietzsche. Entretanto, ele ressalta que o sentimento reativo de culpabilidade não pode estar relacionado à realização do desejo, mas somente ao fato de deixá-lo de lado, e é aqui que ele se aproxima de Nietzsche. Mas, tanto quando Lacan encontra o filósofo quanto quando se separa dele, não se pode afirmar que o campo do desejo possa estar separado daquele da culpabilidade, que possa existir um universo puro onde o desejo reine como mestre absoluto e onde a culpabilidade esteja definitivamente abolida.

\section{O super-homem e o analista que se autoriza de si mesmo}

Movido por uma leitura de Nietzsche marcada por um fascínio que impediu o aprofundamento necessário, Freud é levado a aproximar o "super-homem" nietzschiano do "pai da horda primitiva" e a indicar, por meio dessa aproximação, o rumo oposto que toma em relação ao filósofo. Entretanto, é justamente quando parece buscar indicar as suas diferenças, com relação ao que sustenta o filósofo, é que Freud mostrase surpreendentemente próximo de suas ideias. Talvez possamos afirmar, parafraseando o comentário de Zizek, sobre o hegelianismo de Lacan (Zizek, 1988/91, p. 7), que Freud é nietzschiano não tanto onde espera ser, em suas referências explícitas ao filósofo, mas, antes, ali onde não sabe que o é.

Como buscamos sustentar, a aproximação sugerida por Freud entre o "super-homem" e o "pai da horda" está baseada em uma série de equívocos, o que o leva a situar num passado caduco a mesma figura que Nietzsche espera encontrar no futuro. Seguindo, entretanto, um viés de leitura de Nietzsche diferente daquele empreendido por Freud, e levando em consideração as aproximações não explicitadas entre ambos os autores, mas que permanecem latentes ao texto freudiano, talvez possamos apontar que a perspectiva de surgimento do super-homem, não num passado caduco, mas na conclusão de um processo ético, não se encontra necessariamente ausente da concepção psicanalítica. Não sem antes lembrar que nada mais distante da ideia nietzschiana de "super-homem" do que a ideia de uma espécie de homem superior, de um homem aperfeiçoado ou melhorado, - lembrança necessária para não dar lugar a mal-entendidos - consideramos ser possível indicar uma série de afinidades entre o processo que conduz ao surgimento, no final da análise, do analista, o qual, segundo os termos de Lacan, não pode senão se autorizar de si mesmo, e o processo de transmutação de valores que torna possível o surgimento do "super-homem". A ideia fundamental que permite, a nosso ver, essa aproximação, é a ideia de decadência. É, portanto, sobretudo ao levarmos em consideração a noção nietzschiana de decadência que somos levados a aproximar o "super-homem" não mais ao "pai da horda", cuja morte inaugura a história da moral, mas sim ao analista, cujo surgimento só pode se dar ao final de um processo analítico.

Sem nenhuma sombra de dúvida, Nietzsche lê a história do homem como a história de uma decadência, de um declínio. Como ele próprio afirma, ao homem que "antes havia sido quase um Deus" (Nietzsche, 1887/1971, p. 186), não resta senão o desprezo por si mesmo e o "pungente sentimento de seu nada" (Nietzsche, 1887/1971, p. 186). O Bárbaro - ou, como o chama Nietzsche, a "soberba besta loura" (Nietzsche, 1887/1971, p. 40), indiferente à segurança e ao bem-estar - deu lugar ao Europeu Moderno, ao "verme 'homem" (Nietzsche, 1887/1971, p. 42), ao "homem aprisionado, irremediavelmente medíocre e desolador" (Nietzsche, 1887/1971, p. 42).

O triste espetáculo do declínio do homem não tende, segundo Nietzsche, a mudar de rumo. Muito pelo contrário, afirma ele:

Não vemos nada que queira se tornar maior e pressentimos que o que vemos vai continuar a descer, sempre mais para baixo, em direção ao que houver de mais inconsistente, de mais inofensivo, de mais prudente, de mais acomodado, de mais medíocre, de mais indiferente, de mais chinês, de mais cristão... Doravante, o espetáculo que oferece o homem cansa. (...) Estamos cansados do homem... (Nietzsche, 1887/1971, p. 43)

Diante do espetáculo da decadência, Nietzsche não adota, entretanto, uma posição de combate. E isto porque, a seu ver "a decadência em si mesma não é nada que se precise combater: ela é absolutamente necessária e própria a cada época, a cada povo" (Nietzsche, 1901/1991, p. 95). Ou ainda, dirá ele:

A defecção, a decomposição, o lixo não têm nada de condenável em si mesmo: eles não são senão a conseqüência necessária da vida, do aumento vital. O fenômeno da decadência é tão necessário quanto o desenvolvimento e o progresso da vida: não possuímos meios para suprimir esse fenômeno. Muito pelo contrário, a razão exige que lhe deixemos seus direitos (Nietzsche, 1901/1991, p. 94). 
Mas não apenas é necessário conceder à decadência seus direitos, mas, também admitir que o processo decadencial do homem - o processo de erosão ou de decomposição do homem é irreversível, tendendo necessariamente para o seu fim (Taguieff, 1991, p. 221). Com efeito, se, ao ver de Nietzsche, não cabe sonhar com um aperfeiçoamento impossível do homem, é necessário, para que ele possa ser superado, que o processo de declínio seja conduzido até o seu limite. Em outros termos, se o homem não pode ser melhorado, ele deve, ao contrário, perecer, aniquilar-se. E é da conclusão do processo de decadência, o qual conduz ao aniquilamento do homem, que nascerá o super-homem. É preciso, portanto, que o processo de decadência do homem vá até o seu fim, para que possa emergir das cinzas do homem o super-homem. Assim, afirma Taguieff, "o termo da decadência final, ponto de não-retorno, pode também ser interpretado como um novo começo, re-nascimento, ruptura criadora" (Taguieff, 1991, p. 222).

Entretanto, não se deve compreender a decadência do homem como um destino ao qual seria necessário se resignar, mas como um princípio que é preciso afirmar. $\mathrm{O}$ super-homem não é simplesmente o filho do homem que pereceu, mas, antes, do homem que quer perecer, que quer ir em direção à sua própria perda. Enfim, se o filósofo recusa toda e qualquer moral do aperfeiçoamento ou da melhoria do homem, compreendendo-a como um mal-entendido, ele preconiza uma moral da decadência ou do aniquilamento do homem.

Essa mesma moral da decadência ou essa mesma afirmação da perda de si mesmo se encontra, a nosso ver, na ética psicanalítica. Da mesma forma que Nietzsche, o psicanalista não crê na melhora ou no aperfeiçoamento do homem, ou, mais rigorosamente, ele não erige sua clínica sobre essas ideias. Muito pelo contrário, como afirma Lacan, em termos que o aproximam de forma espantosa de Nietzsche, "cada um sabe que, dada a má situação na qual nós, da espécie humana, nos encontramos, os estragos são o que pode nos acontecer de melhor" (Lacan, 1973, p. 31).

Além disso, a análise, antes de ser um processo de ascensão, é um processo de queda. Longe de implicar um progresso, ela é um processo de queda; e seu fim coincide, não com um crescimento do sujeito e de seu analista, mas sim com a destituição de um e o "des-ser" do outro. Com efeito, como afirma Miller, o fim de uma análise implica que "o sujeito se apague em um tornar-se isso" (Miller, 1994, p.15). Eis a destituição subjetiva. No que concerne ao "des-ser" do analista, como sabemos, ele é a conclusão de um processo que o conduz do lugar de objeto idealizado àquele de resto, ou ainda, daquele do objeto suposto saber àquele de "saber vão de um ser que se subtrai".

Mas se a destituição subjetiva e o des-ser do analista marcam necessariamente a conclusão de uma análise, para que se trate de seu fim - ou seja, do surgimento de um analista ali onde havia o analisando -, é preciso que esse sujeito que conheceu a destituição subjetiva decida ocupar um lugar sobre o qual, como afirma Lacan, "ele não sabe nada, a não ser aquilo a que, em sua experiência, ela reduziu o ocupante", a saber "o lixo, a merda, para chamá-lo por seu nome" (Lacan,1970, p. 25). Enfim, o fim da análise, diferentemente de sua simples conclusão, implica que o sujeito - tal como o homem forte nietzschiano, que "ama e afirma seu próprio declínio" - decida fazer a experiência de uma queda que o conduzirá de um lugar idealizado àquele do lixo. Segundo os termos de Lacan: "O psicanalista, como se diz, quer ser a merda, mas nem sempre a mesma. Isso é interpretável, com a condição que ele perceba que ser a merda é verdadeiramente o que ele quer, desde que ele se faz o testa-de-ferro do sujeito-suposto-saber" (Lacan, 1970, p. 24).

Assim, os temas do declínio, da queda ou da autodestruição são próprios tanto ao percurso do homem em direção ao super-homem quanto ao do analisando em direção ao analista. Tanto o super-homem quanto o analista só podem surgir ao termo de um processo de declínio, decadência ou queda; e, mais, ainda, o surgimento de ambos implica uma mudança de posição do homem (no caso de Nietzsche) ou do sujeito (no caso de Lacan): não simplesmente submeter-se à sua decadência, mas afirmá-la. Desejar morrer para poder surgir de uma nova forma.

\section{Referências}

Assoun, P.-L. (1989). Freud e Nietzsche: Semelhanças e dessemelhanças (M. L. Pereira, Trad.). São Paulo: Brasiliense. (Original publicado em 1980)

Assoun, P. -L. (1998). Freud et Nietzsche. Paris: Quadrige/ P.U.F. (Original publicado em 1980)

Foucault, M. (1982). Microfisica do poder (R. Machado, Trad.). Rio de Janeiro: Graal.

Freud, S. (1993). Totem et tabou (M. Webwe, Trad.). Paris: Gallimard. (Original publicado em 1913)

Freud, S. (1981). Psychologie des foules et analyse du moi. In Freud, S., Essais de psychanalyse (P. Cotet, A. Bourguignon, J. Altounian, O. Bourguignon, \& A. Rauzy, Trads.), Paris: P.B.P. (Original publicado em 1921)

Freud, S. (1966). Correspondance avec le pasteur Pfister 1909-1939 (L. Jumel, Trad.). Paris: Gallimard. (Original publicado em 1963)

Heidegger, M. (2008). Ensaios e conferências (E. C. Leão, G. Fogel, \& M. S. C. Schuback, Trads.). Rio de Janeiro: Vozes. (Original publicado em 1958)

Heidegger, M. (1962). Chemins qui ne mènent nulle part (W. Brokmeier, Trad.). Paris: Gallimard. (Original publicado em 1949)

Lacan, J. (1988). O seminário, Livro VII (A. Quinet, Trad.). Rio de Janeiro: Jorge Zahar. (Original publicado em 1959)

Lacan, J. (1970). Discours prononcé par J. Lacan le 6 décembre 1967 à l'E.F.P. Scilicet, 2/3, 9-29.

Lacan, J. (1973). Intervention sur la passe (texto pronunciado no Congresso da E.F.P. em Montpellier em novembro de 1973). Bulletin de l'Association Freudienne, 45, 27-31. 
Lacan, J. (1974). Télévision. Paris: Seuil.

Miller, J. A. (1994). Donc, je suis ça (La cause freudienne. Revue de psychanalyse, n. 27). In J. A. Miller, La passe: Fait ou fiction? (pp. 9-20). Paris: l'École de la Cause Freudienne.

Nietzsche, F. (1995). Humain, trop humain (H. Albert, Trad.). Paris: Le Livre de Poche, Librairie Générale Française. (Original publicado em 1880)

Nietzsche, F. (1971). Ainsi parla Zarathoustra (M. de Gandillac, Trad., Gallimard, n. 8). Paris: Folio/Essais. (Original publicado em 1884)

Nietzsche, F. (1971). Par-delà bien et mal (C. Heim, Trad., Gallimard, n. 70). Paris : Folio/Essais.(Original publicado em 1886)

Nietzsche, F. (1971) La généalogie de la morale (I. Ildebrand \& J. Gratien, Trads., Gallimard, n. 16). Paris: Folio/ Essais. (Original publicado em 1887)

Nietzsche, F (1991). La volonté de puissance (H. Albert, Trad., Librairie Générale Française, n. 14.). Paris: Le Livre de Poche, Livrarie Génerale Française. (Original publicado em 1901)

Taguieff, P. A. (1991). Nietzsche dans la rhétorique réactionnaire. In P. A. Taguieff, Pourquoi nous ne sommes par nietzschéens (pp. 217-305). Paris: Bernard Grasset.

Zizek, S. (1991). O mais sublime dos histéricos (V. Ribeiro, Trad.). Rio de Janeiro: Jorge Zahar Editor. (Original publicado em 1988).

Simone Perelson é pós-doutora pela Université de Paris VII - Université Denis Diderot. Professora-visitante do Programa de Pós-graduação em Teoria Psicanalítica da Universidade Federal do Rio de Janeiro.

Recebido: 10/11/2008

$1^{a}$ revisão: $14 / 12 / 2008$

$2^{a}$ revisão: 01/04/2009

Aceite final: 08/04/2009 